\title{
Seismic velocity and Poisson's ratio tomography of the crust beneath southwest Anatolia: an insight into the occurrence of large earthquakes
}

\author{
Mohamed K. Salah • Sakir Sahin • Cem Destici
}

Published online: 10 May 2008

(C) Springer Science + Business Media B.V. 2008

\section{Erratum to: J Seismol \\ DOI 10.1007/s10950-007-9062-2}

Unfortunately, the authors' affiliations were incorrect and should appear as shown below.

The online version of the original article can be found under doi: 10.1007/s10950-007-9062-2.

M. K. Salah

Geology Department, Faculty of Science, Tanta University, 31527 Tanta, Egypt

S. Sahin $(\bowtie)$

Geophysical Department,

Faculty of Engineering and Architecture,

Suleyman Demirel University,

Cunur 32260 Isparta, Turkey

e-mail: sakir@mmf.sdu.edu.tr

C. Destici

Belbasi Turkish National Data Center,

Kandilli Observatory and Earthquake Research Institute,

Bogazici University,

Belbasi, Ankara, Turkey 